Prepared in cooperation with the Public Utility District \#1 of Lewis County, Washington

Evaluation of Angler Effort and Harvest of Rainbow Trout (Onchorhynchus mykiss), Lake Scanewa, Washington, 2010

Open-File Report 2011-1178 



\section{Evaluation of Angler Effort and Harvest of Rainbow Trout (Oncorhynchus mykiss), Lake Scanewa, Washington, 2010}

By Theresa L. Liedtke, Tobias J. Kock, Brian K. Ekstrom, Ryan G. Tomka, and Dennis W. Rondorf

Prepared in cooperation with the Public Utility District \#1 of Lewis County, Washington

Open-File Report 2011-1178

U.S. Department of the Interior

U.S. Geological Survey 


\section{U.S. Department of the Interior \\ KEN SALAZAR, Secretary}

\section{U.S. Geological Survey \\ Marcia K. McNutt, Director}

U.S. Geological Survey, Reston, Virginia: 2011

For more information on the USGS-the Federal source for science about the Earth, its natural and living resources, natural hazards, and the environment, visit http://www.usgs.gov or call 1-888-ASK-USGS.

For an overview of USGS information products, including maps, imagery, and publications, visit http://www.usgs.gov/pubprod

To order this and other USGS information products, visit $h$ ttp://store.usgs.gov

Any use of trade, product, or firm names is for descriptive purposes only and does not imply endorsement by the U.S. Government.

Although this report is in the public domain, permission must be secured from the individual copyright owners to reproduce any copyrighted material contained within this report.

Suggested citation:

Liedtke, T.L., Kock, T.J., Ekstrom, B.K., Tomka, R.G., and Rondorf, D.W., 2011, Evaluation of angler effort and harvest of rainbow trout (Onhorhynchus mykiss), Lake Scanewa, Washington, 2010: U.S. Geological Survey OpenFile Report 2011-1178, 24 p. 


\section{Contents}

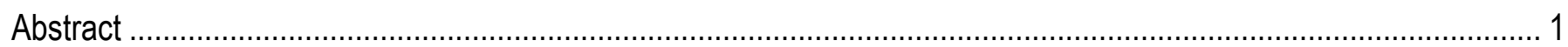

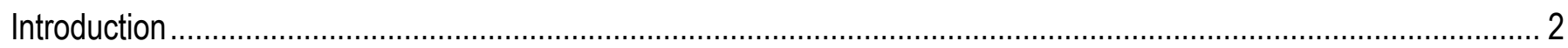

Methods

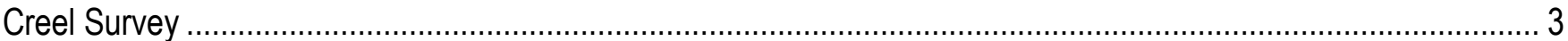

Estimating Angler Effort and Rainbow Trout Harvest ................................................................................ 4

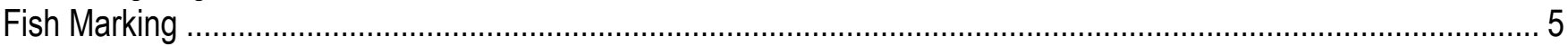

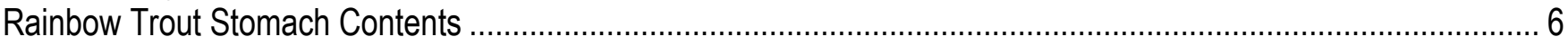

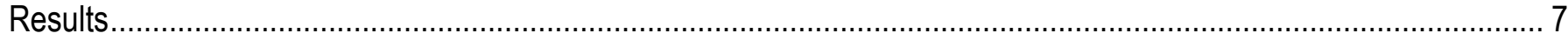

Observed Angler Effort, Catch, and Catch Rates ....................................................................................

Proportion of Daylight Hours Surveyed ..................................................................................................

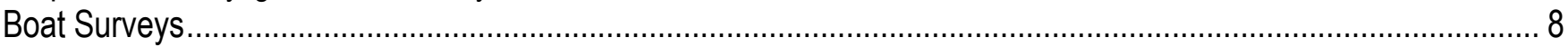

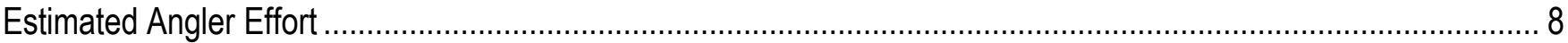

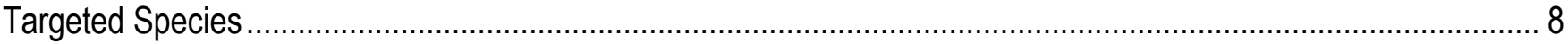

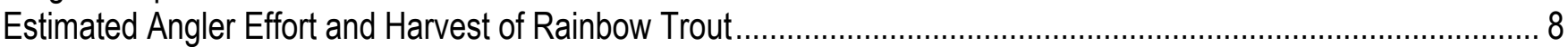

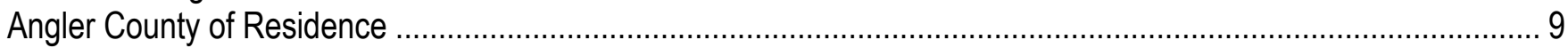

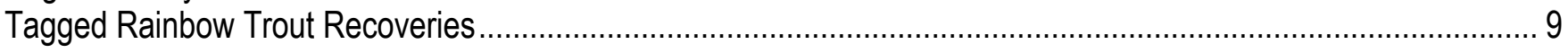

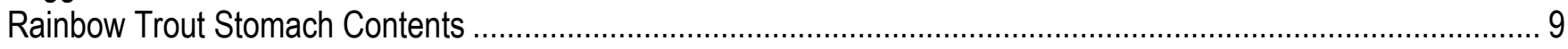

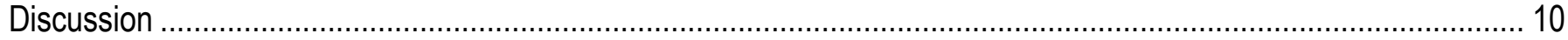

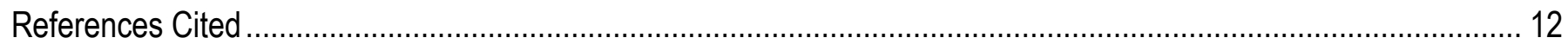

\section{Figures}

Figure 1. Map showing the Upper Cowlitz River Basin and Lake Scanewa study area

Figure 2. Flow chart showing the process that was used to estimate angler effort and harvest numbers of rainbow trout in Lake Scanewa during June-November 2010.

Figure 3. Graph showing the proportion of anglers targeting rainbow trout, salmon, or northern pikeminnow in Lake Scanewa during June-November 2010.

Figure 4. Graph showing the proportion of PIT-tagged rainbow trout that were recovered at three locations in Lake Scanewa during June-November 2010 following release at one of four release locations.

Figure 5. Graph showing the distribution of elapsed times from release to recapture for PIT-tagged rainbow trout

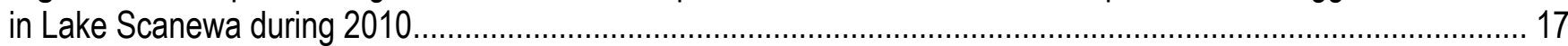

Figure 6. Graph showing the percent of rainbow trout stomachs that contained fish from February 2010 to February 2011

\section{Tables}

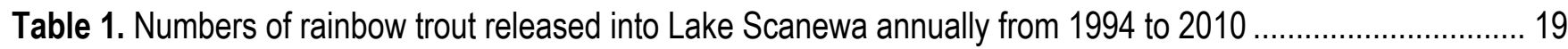

Table 2. Numbers of rainbow trout released at four release sites in Lake Scanewa during 2010 .......................... 19

Table 3. Numbers of fish that were reported in the catch by boat and shore anglers in Lake Scanewa during a creel survey in June-November 2010

Table 4. Catch per hour estimates for rainbow trout anglers in Lake Scanewa during June-November 2010........ 20

Table 5. Summary of the total hours of daylight in each month during June-November 2010, the total number of hours that a creel survey was conducted during this period, and the proportion of daylight hours that were sampled during each mont. 
Table 6. Summary of the number of anglers that were observed from a boat during a creel survey in Lake Scanewa during 2010.

Table 7. Summary of the estimated number of hours that anglers spent in Lake Scanewa during 2010

Table 8. Summary of observed angler effort, proportion of daylight hours that were surveyed, estimated angler effort, observed catch rates, and estimated catch in Lake Scanewa during 2010

Table 9. Summary of the number of anglers that were interviewed from various counties in Washington state during June-November 2010

\section{Conversion Factors}

Inch/Pound to SI

\begin{tabular}{lcl}
\hline & \multicolumn{1}{c}{ Multiply } & \multicolumn{1}{c}{ Bo obtain } \\
\hline inch (in.) & Length & \\
inch (in.) & 2.54 & centimeter (cm) \\
foot (ft) & 25.4 & millimeter (mm) \\
mile (mi) & 0.3048 & meter (m) \\
mile, nautical (nmi) & 1.609 & kilometer (km) \\
\hline & 1.852 & kilometer (km) \\
\hline acre & Area & \\
\hline & 0.4047 & hectare (ha) \\
\hline pound, avoirdupois (lb) & Mass & \\
\hline
\end{tabular}

SI to Inch/Pound

\begin{tabular}{lll}
\hline \multicolumn{1}{c}{ Multiply } & \multicolumn{1}{c}{ By } & To obtain \\
\hline & Length & \\
\hline centimeter $(\mathrm{cm})$ & 0.3937 & inch (in.) \\
millimeter $(\mathrm{mm})$ & 0.03937 & inch (in.) \\
\hline & Area & \\
\hline hectare (ha) & 2.471 & acre \\
\hline & Mass & \\
\hline gram $(\mathrm{g})$ & 0.03527 & ounce, avoirdupois (oz) \\
\hline
\end{tabular}




\title{
Evaluation of Angler Effort and Harvest of Rainbow Trout (Oncorhynchus mykiss), Lake Scanewa, Washington, 2010
}

By Theresa L. Liedtke, Tobias J. Kock, Brian K. Ekstrom, Ryan G. Tomka, and Dennis W. Rondorf

\begin{abstract}
A creel evaluation was conducted in Lake Scanewa, a reservoir on the Cowlitz River, to monitor catch rates of rainbow trout (Oncorhynchus mykiss) and determine if the trout fishery was having negative impacts on juvenile anadromous salmon (Oncorhynchus spp.) in the system. The trout fishery, which is supported by releases of 20,000 fish ( 2 fish per pound) per year from June to August, was developed to mitigate for the construction of Cowlitz Falls Dam in 1994. The trout fishery has a target catch rate of at least 0.50 fish per hour. Interviews with 1,214 anglers during the creel evaluation found that most anglers targeted rainbow trout (52 percent) or Chinook and coho salmon (48 percent). The interviewed anglers caught a total of 1,866 fish, most of which were rainbow trout (1,213 fish; 78 percent) or coho salmon (311 fish; 20 percent). We estimated that anglers spent 17,365 hours fishing in Lake Scanewa from June to November 2010. Catch rates for boat anglers (1.39 fish per hour) exceeded the 0.50 fish per hour target, whereas catch rates for shore anglers $(0.35$ fish per hour $)$ fell short of the goal. The combined catch rates for all trout anglers in the reservoir were 0.96 fish per hour. We estimated that anglers harvested 7,584 (95 percent confidence interval $=2,795-12,372$ fish) rainbow trout during the study period and boat anglers caught more fish than shore anglers $(5,975$ and 1,609 fish, respectively). This estimate suggests that more than 12,000 of the 20,000 rainbow trout released into Lake Scanewa during 2010 were not harvested, and could negatively impact juvenile salmon in the reservoir through predation or competition. We examined 1,236 stomach samples from rainbow trout and found that 2.1 percent (26 fish) of these samples contained juvenile fish. Large trout (greater than 300 millimeters) had a higher incidence of predation than small trout (less than 300 millimeters; 8.50 and 0.06 percent, respectively). A total of 39 fish were found in rainbow trout stomachs and 13 (33 percent) of these were juvenile salmon. These data and uncertainties associated with movement patterns and survival rates of rainbow trout in Lake Scanewa suggest that future evaluations would be helpful to better understand the potential effects of the mitigation trout fishery on juvenile salmon in the reservoir.
\end{abstract}




\section{Introduction}

Thousands of rainbow trout are released annually into Lake Scanewa, a reservoir on the upper Cowlitz River (fig. 1), to support a popular sport fishery that was created to mitigate for the construction of Cowlitz Falls Dam in 1994. The fish releases are funded by Lewis County Public Utility District (LCPUD) to meet a license requirement for the operation of Cowlitz Falls Dam. This requirement was established by the Federal Energy Regulatory Commission (FERC) to create a sport fishery in Lake Scanewa with catch rates that meet or exceed 0.50 fish per hour. Creel surveys were conducted during 1994, 1995, and 2000 to quantify angler effort, determine by-catch, and document catch rates in Lake Scanewa. These surveys showed that catch rates exceeded the 0.50 fish per hour goal in 1994, but not in 1995 or 2000 (Neeley, 1995; Tipping and Serl, 2000). Annual releases initially comprised 12,500 fish per year (1994-95), and 25,000 fish have been released annually since 1996 (table 1). Based on their findings, Tipping and Serl (2000) recommended that releases be increased to 30,000 fish per year to achieve the desired catch rates for the fishery. However, increasing the number of rainbow trout that are released into the reservoir each year could have negative impacts on other species in the system.

The upper Cowlitz River basin supports anadromous populations of winter steelhead (Oncorhynchus mykiss), coho salmon (O. kisutch), and Chinook salmon (O. tshawytscha) and concerns have been raised about the possibility of planted rainbow trout becoming predatory and feeding upon juvenile anadromous salmon either rearing in, or migrating through Lake Scanewa (National Marine Fisheries Service, 2009). Life history data and observations from the field suggest that juvenile coho salmon and Chinook salmon would be most susceptible to predation by rainbow trout (John Serl, Washington Department of Fish and Wildlife, oral commun., 2010). Juvenile steelhead smolts are relatively large (about 160-200 mm fork length) compared to coho salmon and Chinook salmon (about 100-130 mm fork length). Furthermore, steelhead parr tend to rear in areas upstream of Lake Scanewa, whereas coho salmon and Chinook salmon parr are frequently encountered in the reservoir (John Serl, Washington Department of Fish and Wildlife, oral commun., 2010). Tipping and Serl (2000) examined stomachs of rainbow trout collected during their creel survey and found that salmonids were present in only 1.1 percent of the small trout (less than $300 \mathrm{~mm}$ fork length) they examined. However, 13.6 percent of the stomachs from large trout (greater than $300 \mathrm{~mm}$ fork length) contained salmonids (Tipping and Serl, 2000). The researchers were able to identify two of the salmonids in the trout stomachs as coho salmon and a third fish was identified as a Chinook salmon. Given the observed levels of predation identified in the Tipping and Serl (2000) study, it seems likely that increasing stocking levels of rainbow trout would pose a risk to juvenile salmon in the reservoir.

We conducted a creel survey in Lake Scanewa during 2010 to collect information that could be used to inform future management actions aimed at finding an acceptable balance between maintaining recreational trout fishing opportunities in Lake Scanewa and minimizing risks to juvenile anadromous species in the system. These evaluations included a creel survey designed to monitor angler effort and harvest in Lake Scanewa from June to November 2010. The creel survey provided the opportunity to:

- determine angler effort in Lake Scanewa;

- estimate catch rates to determine compliance with the FERC license requirement;

- estimate total harvest of rainbow trout during the fishing season; and

- collect stomachs from rainbow trout caught in the fishery to examine for the presence of juvenile salmonids.

We also used passive integrated transponder (PIT) tags to mark a subsample of the rainbow trout that were released into Lake Scanewa to better understand growth rates, elapsed time to capture, and movements in the reservoir. 


\section{Methods}

\section{Creel Survey}

A creel survey was conducted from June to November 2010 to document angler effort and harvest in Lake Scanewa following the guidance outlined in the biological opinion (BiOP) for the operation of Cowlitz Falls Dam (National Marine Fisheries Service, 2009). The BiOP provides specific details about the sampling design that is to be used during creel surveys. These details are summarized below.

1. Creel surveys are to be conducted every 5 years to estimate monthly angler effort and harvest by species from June 1 through November 30.

2. Boat and shore anglers are to be counted every 2 hours, from 1 hour after first light to 1 hour before dark, for four randomly assigned weekdays and four weekend and holiday days per month. The four, $16 \mathrm{~h}$ days from each stratum will be broken into 2 days of $8 \mathrm{~h}$ each, thus a total of 8 week days and 8 weekend days will be sampled monthly (totaling $128 \mathrm{~h}$ each month). During June and July, anglers and boat trailers are to be counted every $2 \mathrm{~h}$ at the Day Use Area from 0630 to $1230 \mathrm{~h}$, or from 1430 to $2030 \mathrm{~h}$. These hours will be shortened monthly for the remainder of the creel survey as daylight diminishes.

3. On one weekday and weekend day per month, anglers will be counted from a boat to develop a correction factor for anglers not observed from shore.

4. In between counts, anglers will be interviewed for hours fished, catch by species, number of fish released, length of fish caught, and county of residence.

5. A minimum of 100 stomachs will be taken from trout caught by anglers each month during June-September to check for the presence of juvenile fish.

6. The data collected during the creel survey will be extrapolated to provide monthly estimates of angler effort and catch rates. These data will then be used to estimate harvest of rainbow trout.

These specifications provided the basis of the sampling design that was used during the creel survey in 2010. Additional data also were collected to provide new insights into fishery issues in the reservoir and are described in section, "Fish Marking."

During each month of the creel survey, we randomly selected 8 weekdays and 8 weekend or holiday days to sample. Each sampling day consisted of a continuous $8 \mathrm{~h}$ shift during either the first 8 daylight hours (a.m. shift) or the last 8 daylight hours (p.m. shift) of each day. During each month, four a.m. shifts and four p.m. shifts were conducted (randomly) to achieve the 8-day goal for each weekday and weekend/holiday group. To account for changing daylight hours throughout the sampling period (and time changes due to daylight savings time), a.m. shifts were conducted from 0630 to $1430 \mathrm{~h}$ from June to August, from 0730 to $1530 \mathrm{~h}$ from September to October, and from 0630 to $1430 \mathrm{~h}$ during November. Similarly, p.m. shifts were conducted from 1230 to $2030 \mathrm{~h}$ from June to August, from 1130 to $1930 \mathrm{~h}$ during September, from 1030 to $1830 \mathrm{~h}$ during October, and from 0930 to $1730 \mathrm{~h}$ during November. 
Creel surveys were conducted primarily at the Day Use Area (fig. 1) and several types of data were collected during each shift. Trout anglers can either fish for trout in Lake Scanewa, or in the Derby Site, which is a small inlet to Lake Scanewa located near the boat launch at the Day Use Park. The entrance into the Derby Site is netted off each summer and stocked with 5,000 rainbow trout for anglers to target. However, because the site is netted off and all fish are presumably harvested by anglers, there are likely no effects to salmonids in the system. For this reason, we did not interview anglers at the Derby Site. Staff conducting the creel surveys recorded the number of shore anglers observed from the Day Use Area along with the number of boat trailers present at the boat launch every $2 \mathrm{~h}$ throughout each shift. Additionally, anglers were interviewed to determine: (1) number of hours fished, (2) target species, (3) catch by species, (4) number of fish released, (5) whether they were fishing from a boat or from the shore; and (6) the location (by zone) where each fish was caught. We used the following zones for classifying catch locations:

1. Cowlitz Arm zone.-The Cowlitz Arm zone included the area on the Cowlitz River side of Lake Scanewa located upstream of the confluence of the Cowlitz and Cispus Rivers.

2. Cispus Arm zone.-The Cispus Arm zone included the area on the Cispus River side of Lake Scanewa located upstream of the confluence of the Cowlitz and Cispus Rivers.

3. Reservoir zone.- - The Reservoir zone included the area of Lake Scanewa located downstream of the confluence of the Cowlitz and Cispus Rivers.

4. Cowlitz Falls zone.- The Cowlitz Falls zone was not an option for anglers and included only those fish that were collected at the Cowlitz Falls Dam Fish Collection Facility.

Successful trout anglers were asked to voluntarily provide additional data from fish that were captured and retained. When possible, survey staff measured (fork length, in centimeters) and weighed (total weight, in grams) each trout, removed the stomach, and examined each fish for the presence of a PIT tag.

During 1 weekday and weekend/holiday day each month, survey staff conducted a boat census on Lake Scanewa to document the number of shore and boat anglers that could not be observed from the Day Use Area. This information was used to develop a correction factor for estimating angler effort in Lake Scanewa.

\section{Estimating Angler Effort and Rainbow Trout Harvest}

Data from angler interviews and boat surveys were used to estimate total angler effort in Lake Scanewa from June to November 2010 (fig. 2). Observations from the creel surveys were adjusted to account for angler effort that occurred during daylight hours when creel surveys were not performed. We assumed that angling in the reservoir during nighttime hours was negligible and therefore nighttime angling was not used to estimate total angling effort in our analysis. A correction factor for hours not surveyed was developed by dividing the total number of hours surveyed each month by the total number of daylight hours in that month to determine the monthly proportion of hours that were surveyed (fig. 2). For example, if a total of $50 \mathrm{~h}$ of creel surveys were conducted in a month that contained 200 total daylight hours, then $50 / 200=0.25$, which represents the proportion of daylight hours that were surveyed in the month. The total number of observed angler hours from the monthly creel survey were then divided by the daylight correction factor to estimate the total number of angler hours that occurred in that month. If a total of 100 angler hours were observed in the above example, then 100/0.25=400 estimated angler hours for that month. Total angler effort estimates were calculated for boat and shore anglers. Boat surveys found that some shore anglers were not visible from the Day Use Area during 
creel surveys, so the estimates of total angler hours by shore anglers were corrected to account for this factor. This correction was accomplished by dividing the total number of visible and non-visible (as determined by the boat surveys) anglers by the total number of visible anglers. For example, if 10 anglers were visible from the Day Use Area and 5 additional anglers were observed from the boat, then the correction factor was calculated as $15 / 10=1.5$. This correction was then multiplied by the total number of shore angler hours to determine the final estimate for shore angler hours. In the above example, 400 angler hours $\times 1.5=600$ total estimated angler hours for shore anglers. Estimates of angler effort for boat and shore anglers were then summed to determine the total number of angler effort hours that occurred during the sampling period.

Estimates of total angler hours were used to estimate angler effort and harvest numbers of rainbow trout in Lake Scanewa from June to November 2010. The goal of the creel survey was to determine catch rates of rainbow trout in the reservoir while also providing information on the potential impacts that rainbow trout could be having on anadromous salmonids in the system. As a result, we estimated total harvest of rainbow trout during the sampling period as a means of understanding the number of rainbow trout that possibly remained in the reservoir after the fishing season. During the creel survey, anglers were interviewed to determine target species in each month. Target species were then grouped into three categories (rainbow trout, salmon, other) and the proportion of each targeted group was determined for boat and shore anglers each month (fig. 2). For example, if 10 shore anglers were interviewed in a month and 5 were targeting rainbow trout, 3 were targeting salmon, and 2 were targeting northern pikeminnow (Ptychocheilus oregonensis), then the proportion of targeted species for that month would be 0.5 for rainbow trout, 0.3 for salmon, and 0.2 for other species. The proportion of anglers targeting rainbow trout each month were multiplied by the total angler effort estimates to determine total angler effort for rainbow trout by boat and shore anglers each month (fig. 2). Using the previous example, 600 estimated angler hours $\times 0.5=300$, which would be the estimate for the total number of angler hours expended by shore anglers for rainbow trout in that month. Monthly catch rates for rainbow trout were determined by dividing the total number of trout caught by each angler during the period of time in which they fished. This number was then multiplied by the rainbow trout angler effort estimates to estimate the number of trout harvested by boat and shore anglers each month. For example, if the monthly catch rate by shore anglers was calculated as 1.5 fish per hour, then 300 angler hours targeting trout $\times 1.5=450$, which is the estimated number of trout harvested by shore anglers in the above example. Boat and shore estimates were summed to determine the total harvest estimate for all anglers during the sampling period.

\section{Fish Marking}

We used PIT tags to mark approximately 10 percent of the rainbow trout that were released into Lake Scanewa during 2010 to better understand fish movements and residence time in the reservoir. The PIT tags allowed unique identification of marked individual fish. Rainbow trout were released into Lake Scanewa six times from June to August 2010 to provide angling opportunities throughout the summer fishing season (table 2). Fish typically are released at four sites on each release day (fig. 1): (1) the Bud Allen Campground; (2) the Cispus Arm of Lake Scanewa; (3) the Day Use Area; and (4) the PUD Boat Launch. Fish were PIT tagged and released at each release site on each scheduled release date and then monitored for PIT-tag presence during creel survey events and at the Cowltiz Falls Fish Collection Facility. Re-collection of PIT-tagged fish provided several pieces of information. For example, we could examine movements from release locations by comparing the location where each fish was recovered to the location where it was released. We also could examine residence times in the reservoir by subtracting the recovery date of a given fish from its release date. 
On each stocking date, fish were transported from the rearing facility near Orting, Washington (about $1 \mathrm{~h}$ transport time) to the Cowlitz Falls Fish Facility where we transferred approximately 12 percent of the fish to be released into a concrete raceway for PIT tagging. Once we obtained fish for tagging, the transport trucks proceeded with normal release procedures in the reservoir. For tagging, fish were hand-netted from the raceway in groups of 4-10 fish, and placed into an electro-anesthesia unit for sedation. Once fish were immobilized, $12.5 \mathrm{~mm}$ PIT tags (Biomark; Boise, Idaho) were injected into each fish near the pelvic girdle. Tagged fish were then transferred to a second electro-anesthesia unit where fork length measurements (to the nearest millimeter) were taken. Tagged fish were then weighed (to the nearest gram) and transferred into an oxygenated holding container that received a continuous supply of river water. We tagged a higher proportion of rainbow trout for the Bud Allen Campground and PUD Boat Launch release sites because we anticipated that these fish would have a lower probability of being harvested than fish from the other release sites. During the study, fish selected for marking (75-107 fish; table 2) from a given release group were tagged, then transported and released. The tagged fish typically were released within $6 \mathrm{~h}$ of untagged fish from the same release group.

\section{Rainbow Trout Stomach Contents}

Rainbow trout stomachs were collected using several techniques from February 2010 to February 2011. Stomachs were collected and preserved for later inspection to understand food habits of rainbow trout in Lake Scanewa and to document predation on juvenile salmonids. To collect stomach samples outside of the creel survey periods, we angled for trout in the reservoir. We angled from February to May 2010, before creel surveys began, and during February 2011. From June to November 2010, stomachs were collected voluntarily from anglers through the creel survey process. Additionally, stomach samples were obtained from all rainbow trout that were collected at the Cowlitz Falls Fish Facility from April to August 2010. Stomach samples were preserved in 85 percent ethanol and were examined in the laboratory using a dissecting microscope. Diet items were divided into one of the following categories: (1) insects, (2) fish, (3) organic items (for example, sticks, rocks, etc.), and (4) unidentifiable items. Fish were identified to species using direct observation when possible. Partially or fully digested fish were identified based on bones that were recovered in the stomach. Once diet items from individual fish were categorized, the total weight of each category was measured to the nearest $0.001 \mathrm{~g}$. 


\section{Results}

\section{Observed Angler Effort, Catch, and Catch Rates}

We interviewed 1,214 anglers who spent 4,594 h fishing in Lake Scanewa from June to November 2010. These anglers targeted rainbow trout (52 percent; 629 anglers), salmon (48 percent; 580 anglers), and northern pikeminnow (less than 1 percent; 5 anglers). Trout angling was most popular from June to September and most anglers pursued salmon in October and November (fig. 3). Boat angling (67 percent; 816 anglers) was more popular than shore angling (32 percent; 398 anglers) and comprised 77 percent $(3,518 \mathrm{~h})$ of the angling effort. Anglers expended the most effort during November (1,470 h), followed by October (1,239 h), August (605 h), July (528 h), September (449 h), and June $(303 \mathrm{~h}$ ). More anglers fished during weekends (737 anglers) than during weekdays (477 anglers). This relationship was reflected in the number of hours fished during these periods (weekends, $2,868 \mathrm{~h}$; weekdays, $1,726 \mathrm{~h}$ ).

A total of 1,866 fish were caught by anglers who were interviewed during the sampling period. Most of the catch was comprised of rainbow trout and coho salmon, although small numbers of Chinook salmon and northern pikeminnow also were caught (table 3). Anglers also caught suckers (Catostomus spp.), mountain whitefish (Prosopium williamsoni), and cutthroat trout (O. clarki) but these species comprised less than 1 percent of the total observed catch. Boat anglers accounted for most of the fish that were caught (table 3). Most rainbow trout were caught in August (51 percent; 713 fish) and July (25 percent; 356 fish). Lesser numbers of rainbow trout were caught during September (14 percent; 199 fish), October ( 5 percent; 66 fish), November ( 3 percent; 47 fish), and June ( 2 percent; 30 fish). Salmon anglers caught most of their fish in November (63 percent; 277 fish) and October (31 percent; 137 fish) while few fish were caught from June to September (6 percent; 26 fish).

Catch rates of rainbow trout were substantially different between boat and shore anglers but overall catch rates exceeded the 0.50 fish per hour goal. Boat anglers averaged catch rates of 1.39 fish per hour throughout the study period, ranging from a low of 0.17 fish per hour in June to a high of 2.05 fish per hour in August (table 4). Shore angler catch rates generally were low, averaging 0.35 fish per hour during the study. The November shore angler catch rates (4.09 fish per hour) were the highest observed for all months regardless of whether anglers were fishing from a boat or from the shore (table 4). Boat anglers exceeded the 0.50 fish per hour goal in all months except June (no boat anglers targeting rainbow trout were interviewed in November). Shore anglers exceeded the goal in November only. Overall, combined catch rates ( 0.96 fish per hour) exceeded the 0.50 fish per hour goal during the study period.

\section{Proportion of Daylight Hours Surveyed}

Creel surveys were conducted 16 or $17 \mathrm{~d}$ each month from June to November 2010 and sampling occupied approximately one-third to one-half of the daylight hours in each month. A total of $778 \mathrm{~h}$ of creel surveys were conducted during the study which represented 32 percent of the daylight hours during that period (table 5). Creel surveys were conducted during 27 percent of the daylight hours that occurred from June to August, and then increased to a maximum of 48 percent in November as day length decreased. Creel surveys exceeded the 128 monthly hours required in the BiOp (16 shifts $\times 8$ hours per shift) every month except September, when a scheduling error resulted in failure to meet the monthly requirement. However, our overall creel effort was $778 \mathrm{~h}$, exceeding the requirement by $10 \mathrm{~h}$ (table 5). 


\section{Boat Surveys}

Boat surveys were conducted twice each month to develop a correction factor for anglers that were not visible from the Day Use Area during standard creel surveys. Creel survey staff counted shore and boat anglers during these surveys but found that all boat anglers were accounted for at the Day Use Area, therefore corrections were only applicable to shore anglers. Low numbers of anglers were observed during all boat surveys and correction factors ranged from 1.0 (no correction) to 5.3 (table 6). Most shore anglers that were not visible from the Day Use Area were located on the Cispus Arm of Lake Scanewa where boat angling also was very popular.

\section{Estimated Angler Effort}

We estimated that anglers spent in excess of $17,000 \mathrm{~h}$ fishing in Lake Scanewa from June to November 2010. Angler effort was greatest during October $(4,253 \mathrm{~h}$ ) when most anglers were targeting coho salmon (fig. 3; table 7). Angler effort also was high during August (3,732 h), July (3,394 h), and November (3,053 h; table 7). Angler effort in the reservoir was relatively low during June $(1,103 \mathrm{~h})$ when trout stocking at the Derby Site occurred. Boat anglers spent more time fishing $(9,764 \mathrm{~h})$ in the reservoir than shore anglers $(7,689 \mathrm{~h})$.

\section{Targeted Species}

Anglers were interviewed to determine which species they targeted while fishing in Lake Scanewa. Most anglers targeted rainbow trout from June to September but few anglers pursued trout in October and November when coho salmon were the primary species of interest (table 7; fig. 2). The proportion of anglers that targeted rainbow trout was similar between boat and shore anglers during each month of the study period (table 7). Few anglers (less than 3 percent per month) targeted species other than rainbow trout or salmon during the study period.

\section{Estimated Angler Effort and Harvest of Rainbow Trout}

We estimated that anglers spent nearly $10,000 \mathrm{~h}$ fishing for rainbow trout in Lake Scanewa from June to November 2010. Boat anglers expended the most effort during July $(1,209 \mathrm{~h})$ and August $(1,845$ h) and did not fish for rainbow trout in November (table 8). Shore anglers pursued rainbow trout primarily from July to September (table 8). We estimated that total angler effort for rainbow trout was $9,863 \mathrm{~h}$ (table 7). These estimates indicated that shore anglers expended $1,139 \mathrm{~h}$ more than boat anglers during the sampling period $(5,501 \mathrm{~h}$ for shore anglers; 4,362 $\mathrm{h}$ for boat anglers; table 8$)$.

Estimates of rainbow trout harvest suggest that boat anglers were more successful than shore anglers and total harvest of rainbow trout was estimated to be 7,584 fish during the study period. Monthly harvest by boat and shore anglers was highest in July and August (table 8). Boat anglers caught 3.7 times as many rainbow trout as shore anglers (5,976 fish compared to 1,608 fish; table 8). Boat anglers harvested 3,783 rainbow trout in August, which represented 50 percent of the total harvest for boat and shore anglers during the entire study period. We estimated that total harvest of rainbow trout by boat and shore anglers combined was 7,584 fish (95-percent confidence interval $=2,795-12,372$ fish) from June to November 2010. 


\section{Angler County of Residence}

Most anglers interviewed during the creel survey were from Lewis County, or other neighboring counties, which suggests that the Lake Scanewa fishery consists mostly of anglers located a short distance from the reservoir. Lewis County residents comprised 42 percent of the anglers who were interviewed followed by Pierce County residents (27 percent), Yakima County residents (13 percent), and Thurston County residents (13 percent; table 9). Collectively, these counties produced 89 percent of the anglers who were interviewed during the creel survey in 2010. Small numbers of anglers were either from other counties throughout the State or other States (table 9).

\section{Tagged Rainbow Trout Recoveries}

We recovered 88 of the rainbow trout that were PIT tagged during our study. Most recovered PIT-tagged fish were caught by anglers (50 fish in the Cispus Arm of Lake Scanewa; 12 fish in the Cowlitz Arm of Lake Scanewa), although some fish were recovered following collection at the Cowlitz Falls Fish Collection Facility (26 fish). The 88 fish that were recovered during the study accounted for 4 percent of the fish that were PIT-tagged and released (2,082 fish). Tag recoveries showed that fish dispersed from the various release sites and contributed to catches in the Cowlitz and Cispus Arms of Lake Scanewa, as well as captures at the Cowlitz Falls Fish Collection Facility (fig. 4). The unique identification of the PIT tags allowed us to calculate the elapsed time from release to recapture for recovered PIT-tagged fish. The mean elapsed time from release to recapture was $27.5 \mathrm{~d}(\mathrm{SD}=23.4)$ and ranged from a minimum of $1 \mathrm{~d}$ to a maximum of $100 \mathrm{~d}$ (fig. 5).

\section{Rainbow Trout Stomach Contents}

We collected a total of 1,236 rainbow trout stomachs during the study period and examination of these samples showed that some trout were predatory in Lake Scanewa. Most stomach samples were obtained from fish that were caught in the Cispus Arm of Lake Scanewa ( 859 fish), followed by fish from the Cowlitz Falls Fish Collection Facility (271 fish), and fish from the Cowlitz Arm of Lake Scanewa (106 fish). Predation rates were highest for fish from the Cispus Arm of Lake Scanewa (2.7\%; 23 of 859 fish), followed by fish from the Cowlitz Falls Fish Collection Facility (1.5\%; 4 of 271 fish), and fish from the Cowlitz Arm of Lake Scanewa (0.009\%; 1 of 106 fish). A total of 28 trout stomachs (2.3 percent) contained fish, showing a low overall level of predation. Of the trout that consumed fish, we found 13 salmonid prey and 26 non-salmonid prey. Of the salmon that were consumed, 9 were found in stomachs of fish from the Cispus Arm of Lake Scanewa, 4 were from stomachs of fish from the Cowlitz Falls Fish Collection Facility, and none was found in stomachs of fish from the Cowlitz Arm of Lake Scanewa. A higher percentage of large trout (greater than $300 \mathrm{~mm}$ fork length; 8.5 percent) had fish in their stomachs compared to small trout (less than $300 \mathrm{~mm}$ fork length; 0.06 percent). Of the trout stomachs containing fish, 77 percent (20 of 26 fish) were from large trout. Most of the fish in trout stomachs were non-salmonid species (67 percent; 26 fish). Only 13 of the 39 fish in trout stomachs were from salmon species. We observed that predation by large trout varied seasonally based on the month in which trout stomachs were obtained (fig. 6). Predation was highest during February, March, and May and was relatively low (less than 10 percent) during July-September. 


\section{Discussion}

Results from the 2010 creel evaluation show that catch rates for trout anglers exceeded the 0.50 fish per hour goal. Catch rates and angler effort varied between boat and shore anglers and few anglers' targeted rainbow trout during October and November. The combined catch rates for boat and shore anglers (0.96 fish per hour) were nearly double the 0.50 fish per hour catch rate goal, which suggests that the mitigation trout fishery is successful in Lake Scanewa. Boat anglers were particularly successful as evidenced by the 1.39 fish per hour catch rates observed over the course of the study period. Shore anglers were less successful with overall catch rates ( 0.35 fish per hour) that did not meet the 0.50 fish per hour goal. However, these catch rate estimates did not include angling that occurred in the Derby Site fishery. The Derby Site is a highly popular shore fishery near the Day Use Area, which is netted off from the reservoir during the fishing season. As a result, fish are contained in a relatively small area (approximately $0.3 \mathrm{ha}$ ) where most or all of the 5,000 fish that are planted are presumably harvested. Catch rate data at this site were not collected as part of our study, but preliminary estimates suggest that catch rates in the Derby Site fishery probably exceeded those which were observed for boat anglers in Lake Scanewa during 2010 (Mike Kohn, Lewis County PUD, oral commun., 2010). Given these data, the mitigation trout fishery in Lake Scanewa appears to provide good angling opportunity, with some risk of negative impacts to anadromous species in the system.

We estimated that trout anglers harvested about 38 percent $(7,584$ fish) of the rainbow trout that were planted into Lake Scanewa during 2010. This harvest estimate leaves nearly 12,500 planted fish unaccounted for that could prey upon, or compete with juvenile anadromous salmon in the system. Catch data from Cowlitz Falls Dam showed that 352 rainbow trout were collected at the fish facility during 2010, which suggests that some fish move downstream and pass the dam. The movements of rainbow trout in Lake Scanewa have not been studied so it is not possible to quantify how many fish could be passing the dam through turbines or the spillway. Catch data at the fish collection facility show significant annual variability in the number of rainbow trout that are collected, ranging from a low of 97 fish in 2008 to a high of 1,009 fish in 1998. Survival rates of rainbow trout in the reservoir are currently not known so we can not estimate the size of the population in the reservoir after the angling season is closed. These limitations prevent us from determining if competition or predation are major factors affecting juvenile salmon in the system, but examination of stomach samples collected during 2010 show that predation is occurring.

Examination of the stomach samples revealed that rainbow trout are preying upon fish in Lake Scanewa and the incidence of predation is higher for larger trout. The creel survey conducted by Tipping and Serl (2000) identified differences between large trout (greater than $300 \mathrm{~mm}$ ) and small trout (less than $300 \mathrm{~mm}$; 13.6 percent predation compared to 1.1 percent predation). We used this size criteria for estimating predation rates of large and small trout during 2010 and observed a similar relationship, although predation rates were lower for both groups in our study. We found that 8.5 percent of large trout and 0.6 percent of small trout had fish in their stomachs but only 2.6 and 0.2 percent had salmonids in their stomachs. Tipping and Serl (2000) reported only the proportion of trout with salmonids in their stomachs, yet their observed predation rates on juvenile salmon were approximately five times higher than this study. We sampled 2,098 rainbow trout prior to release for PIT tagging and found that 6 percent of these fish were larger than $300 \mathrm{~mm}$. Given this relationship, about 1,200 (6 percent of the 20,000 fish) of the rainbow trout likely were larger than $300 \mathrm{~mm}$ when released during 
2010. This is a significant size for a predator population considering that these fish could consume 36,000 juvenile salmon in a 30-d period if they remained in the reservoir and each preyed upon one juvenile salmon per day. These data clearly show that subsequent evaluations will be needed to adequately address questions concerning rainbow trout predation on juvenile salmon in Lake Scanewa.

The possible effects of predation by rainbow trout on juvenile salmonids in Lake Scanewa are cause for concern and the current requirements for monitoring stomach contents during the creel survey may not be adequate for addressing this issue. The current guidance for collecting stomach samples as part of creel surveys includes collecting at least 100 stomach samples per month from June to September for a total of 400 samples that are to be examined for the presence of juvenile fish (National Marine Fisheries Service, 2009). This approach may not be adequate for several reasons. First, rainbow trout are released from June to August when most juvenile salmon in the system are smolt-sized (that is, greater than $100 \mathrm{~mm}$ ), which may make many of these fish too large to be prey items for trout. Second, the trout that are released have been reared in a hatchery facility and their feeding habits in a natural system will likely develop over time. Thus, fish that may become predaceous may not do so until late summer or early fall. This effect would not be observed if efforts to collect stomachs are ended in September. Additionally, food habits will change over time as food availability changes so it could be insightful to examine stomachs throughout the year to better understand these patterns. Finally, fry and parr presence in the reservoir likely peaks during the fall, winter, and early months of the year. Because these fish are appropriately sized to be prey items for rainbow trout, stomach content analysis would be particularly insightful during this time. We made additional efforts to collect stomach samples to address these issues: our final sample size was approximately three times as large as the minimum requirement, and some samples were collected during February, March, and May (fig. 6). Although sample sizes during these periods were small, the results from these samples support our hypothesis that predation could peak from October to May each year. Future evaluations should focus efforts on data collection associated with predation by rainbow trout in Lake Scanewa, as this appears to be the most significant threat associated with the current mitigation trout fishery.

Tipping and Serl (2000) proposed that angler bycatch and hooking mortality from the mitigation trout fishery could have negative consequences for juvenile anadromous salmon but we found little evidence to support these concerns during 2010. Anglers that we interviewed reported catching a total of 1,866 fish, and only one of these was a juvenile anadromous salmonid (cutthroat trout), that was released. Given the low bycatch that we observed, hooking mortality may not currently be an issue for juvenile anadromous salmonids in Lake Scanewa. Since Mongillo (1984) reported that hooking and release mortality rates can approach 50 percent, we recommend monitoring bycatch rates during future creel evaluations.

Using PIT tags to monitor rainbow trout during our evaluation provided additional information that was not previously available from creel evaluations in Lake Scanewa. For example, we found that fish from the various release sites all contributed to collections in the Cowlitz and Cispus Arms of Lake Scanewa and at the Cowlitz Falls Fish Collection Facility (fig. 4). Additionally, we found that the mean time from release to recapture for PIT-tagged fish was $27.5 \mathrm{~d}$ and that many fish were harvested within $30 \mathrm{~d}$ of being released (fig. 5). This was an important finding because we had planned to obtain growth data from PIT-tagged fish but the limited amount of time that fish spent in the reservoir prior to recapture provided little information about growth rates over time. Additional evaluations using radio or acoustic telemetry would provide more information regarding movement patterns and survival rates of rainbow trout in the reservoir. 
Our study provided numerous insights into the status of the mitigation trout fishery in Lake Scanewa and identified several research needs that could inform management processes aimed at maintaining a balance between the mitigation trout fishery and anadromous salmonid populations in Lake Scanewa and the upper Cowlitz River Basin. We found that catch rates were well above the management goals and observed that some degree of predation is occurring in the reservoir, although current information deficiencies prevented us from quantifying predation throughout the year. Data obtained during this study should prove useful in developing future studies that inform management decisions in the upper Cowlitz River Basin.

\section{References Cited}

Mongillo, P.E., 1984, A summary of salmonid hooking mortality: Washington Department of Game, Olympia, Washington.

National Marine Fisheries Service, 2009, Endangered Species Act Section 7(a)(2) Consultation:

Biological Opinion and Magnuson-Stevens Fishery Conservation and Management Act Essential Fish Habitat Consultation: NOAA, Log number 2002/00945.

Neeley, D., 1995, Creel surveys at the Cowlitz Falls Reservoir: 1995 Report, InSTATS, Oregon City, Oregon.

Tipping, J.M., and Serl, J.D., 2000, Lake Scanewa creel census for 2000: 2000 Report, Washington Department of Fish and Wildlife, Olympia, Washington. 


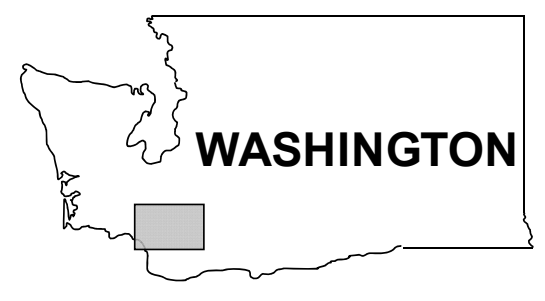

\section{Bud Allen}

Campground

release site

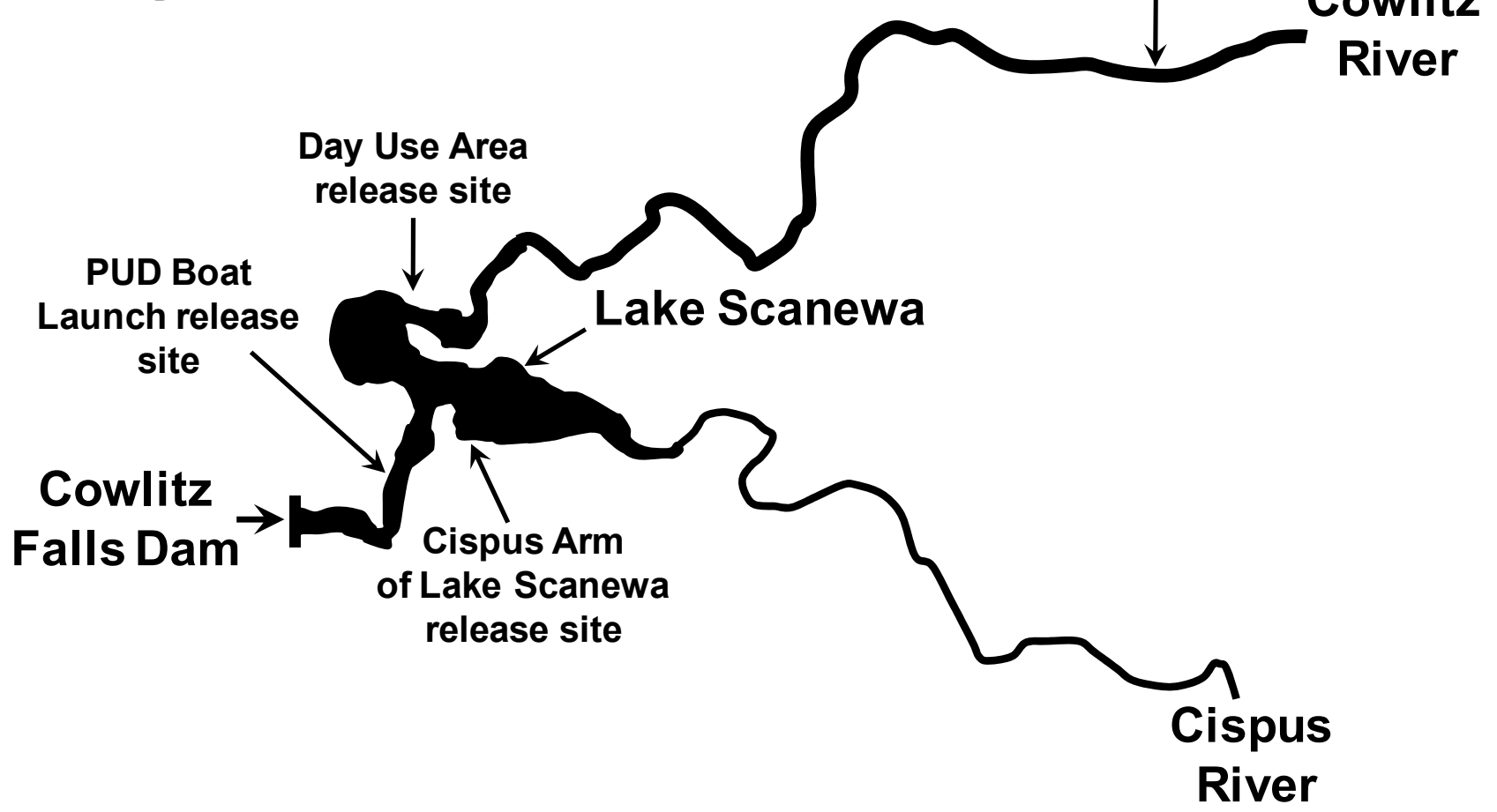

Figure 1. Map showing Upper Cowlitz River Basin and Lake Scanewa study area, Washington. 


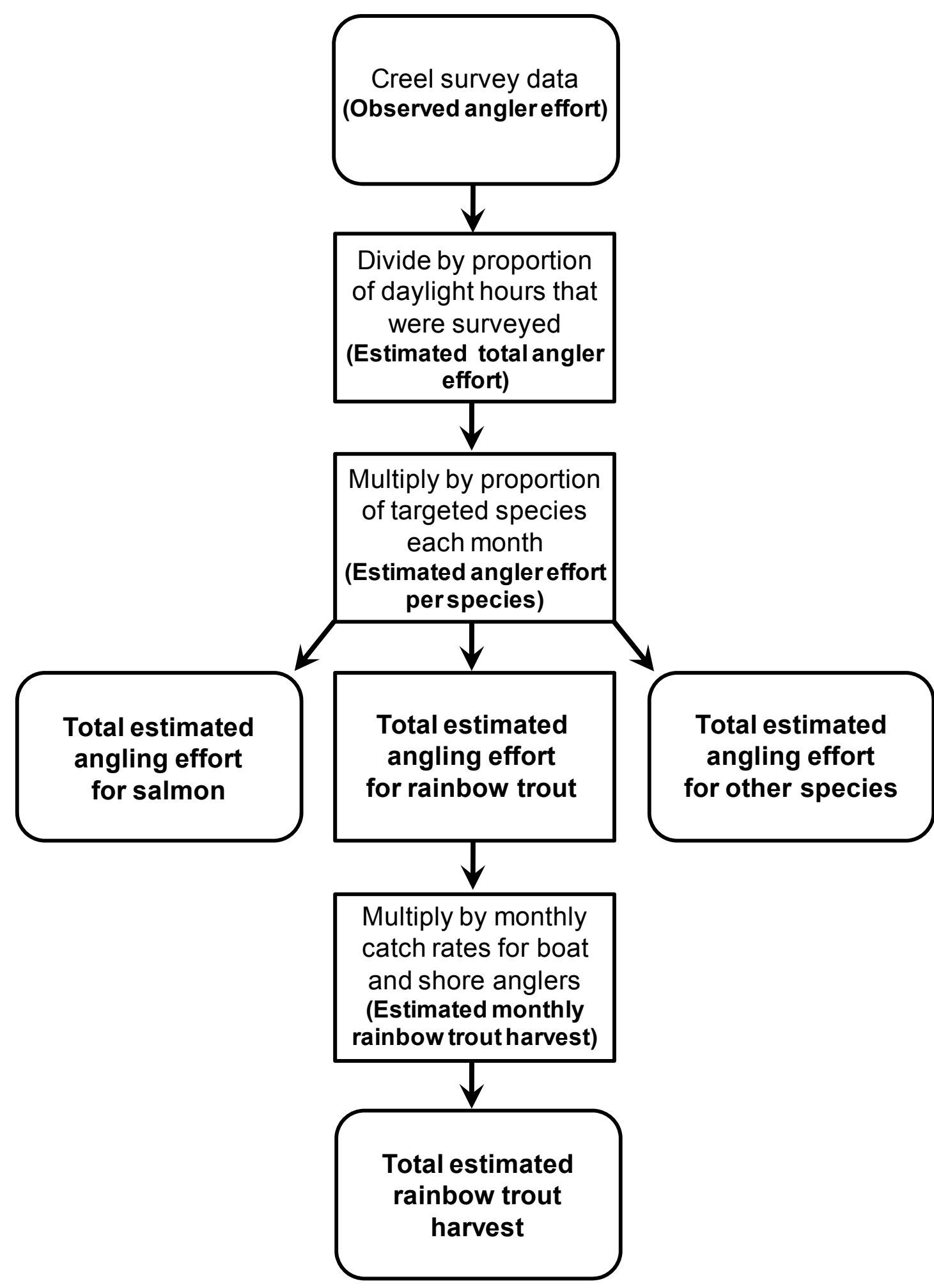

Figure 2. Flow chart showing process that was used to estimate angler effort and harvest numbers of rainbow trout in Lake Scanewa, Washington, June-November 2010. 


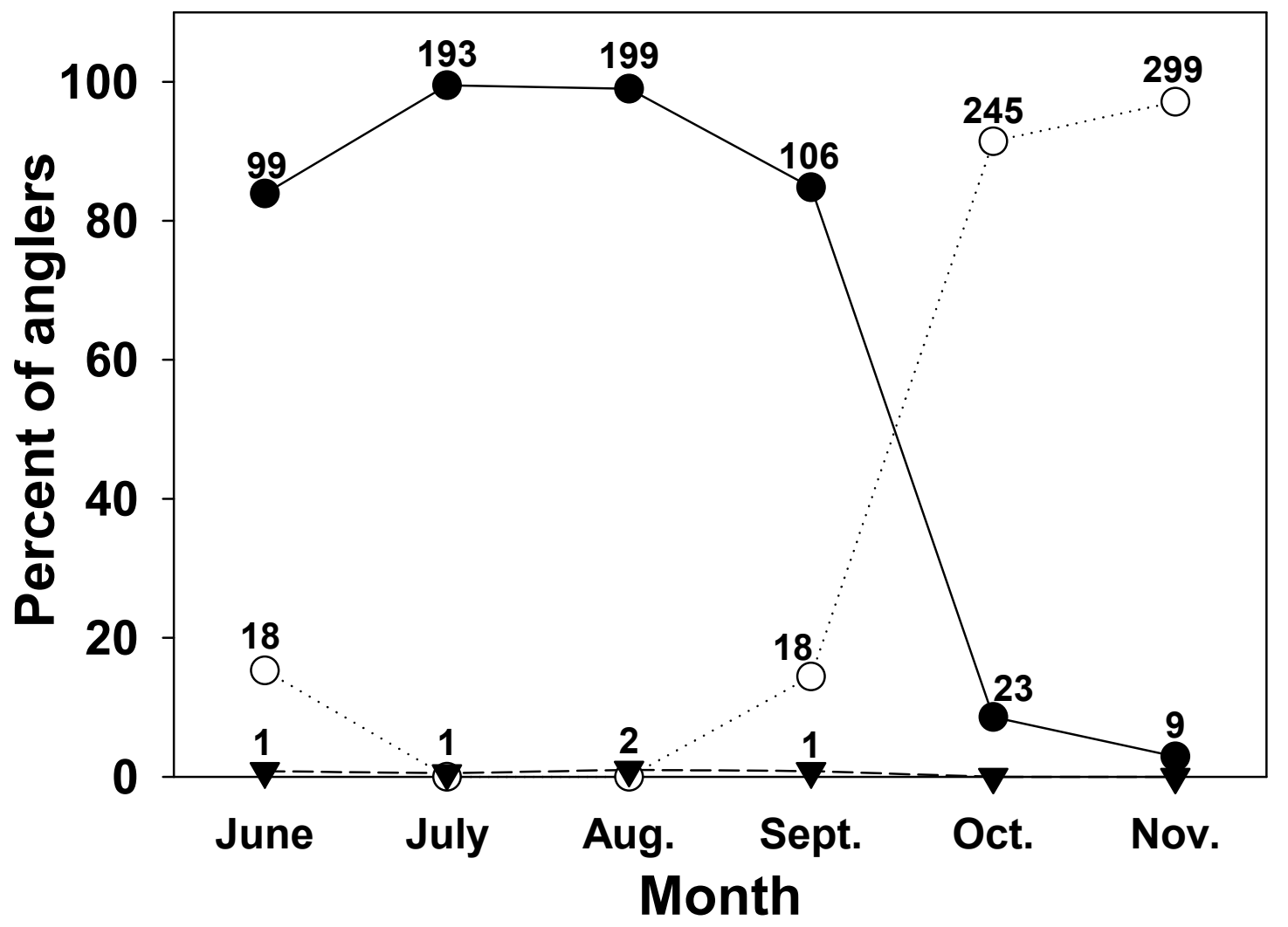

Figure 3. Graph showing proportion of anglers targeting rainbow trout (filled circles), salmon (open circles), or northern pikeminnow (filled triangles) in Lake Scanewa, Washington, June-November 2010. Salmon anglers were targeting Chinook salmon (June-August) and coho salmon (September-November). Numbers above symbols represent the number of anglers targeting each species. 


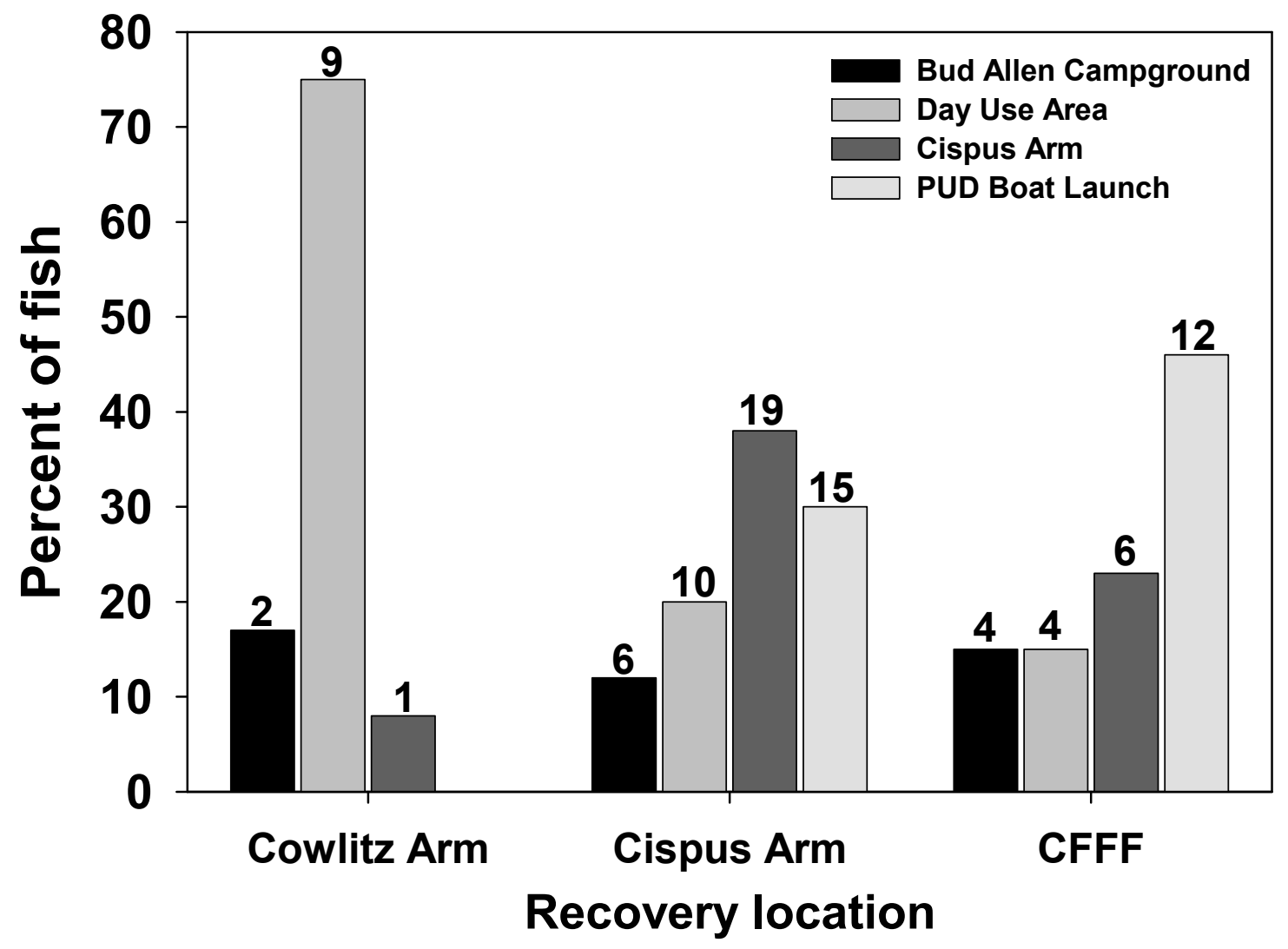

Figure 4. Graph showing proportion of PIT-tagged rainbow trout that were recovered at three locations in Lake Scanewa, Washington, June-November 2010, following release at one of four release locations (Bud Allen Campground, Day Use Area, Cispus Arm of Lake Scanewa and PUD Boat Launch). Recovery locations included the Cowlitz Arm of Lake Scanewa, the Cispus Arm of Lake Scanewa, and the Cowlitz Falls Fish Collection Facility (CFFF). All fish were recovered by anglers except those from the CFFF which were recovered through the collection process. 


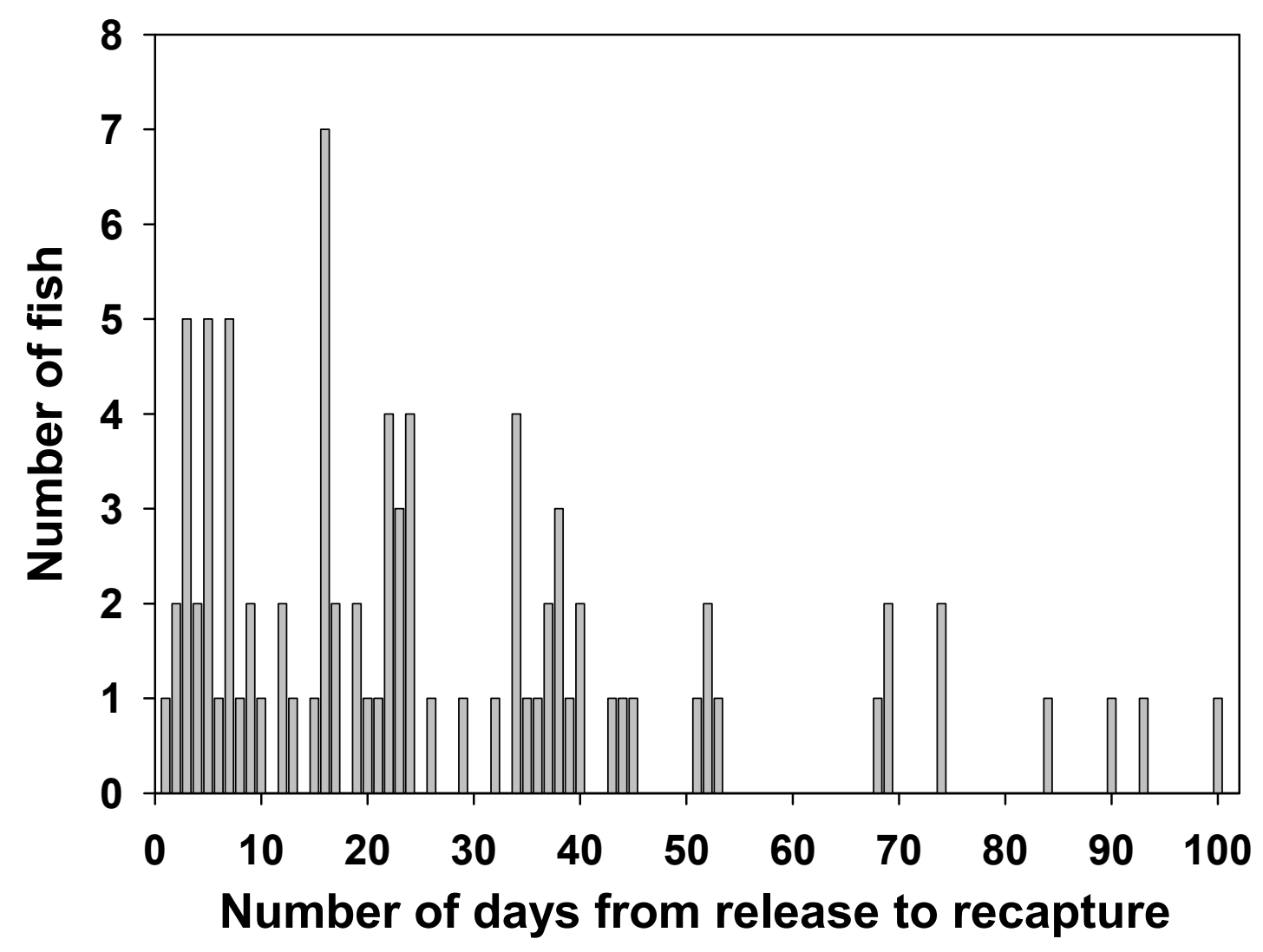

Figure 5. Graph showing distribution of elapsed times from release to recapture for PIT-tagged rainbow trout in Lake Scanewa, Washington, 2010. 


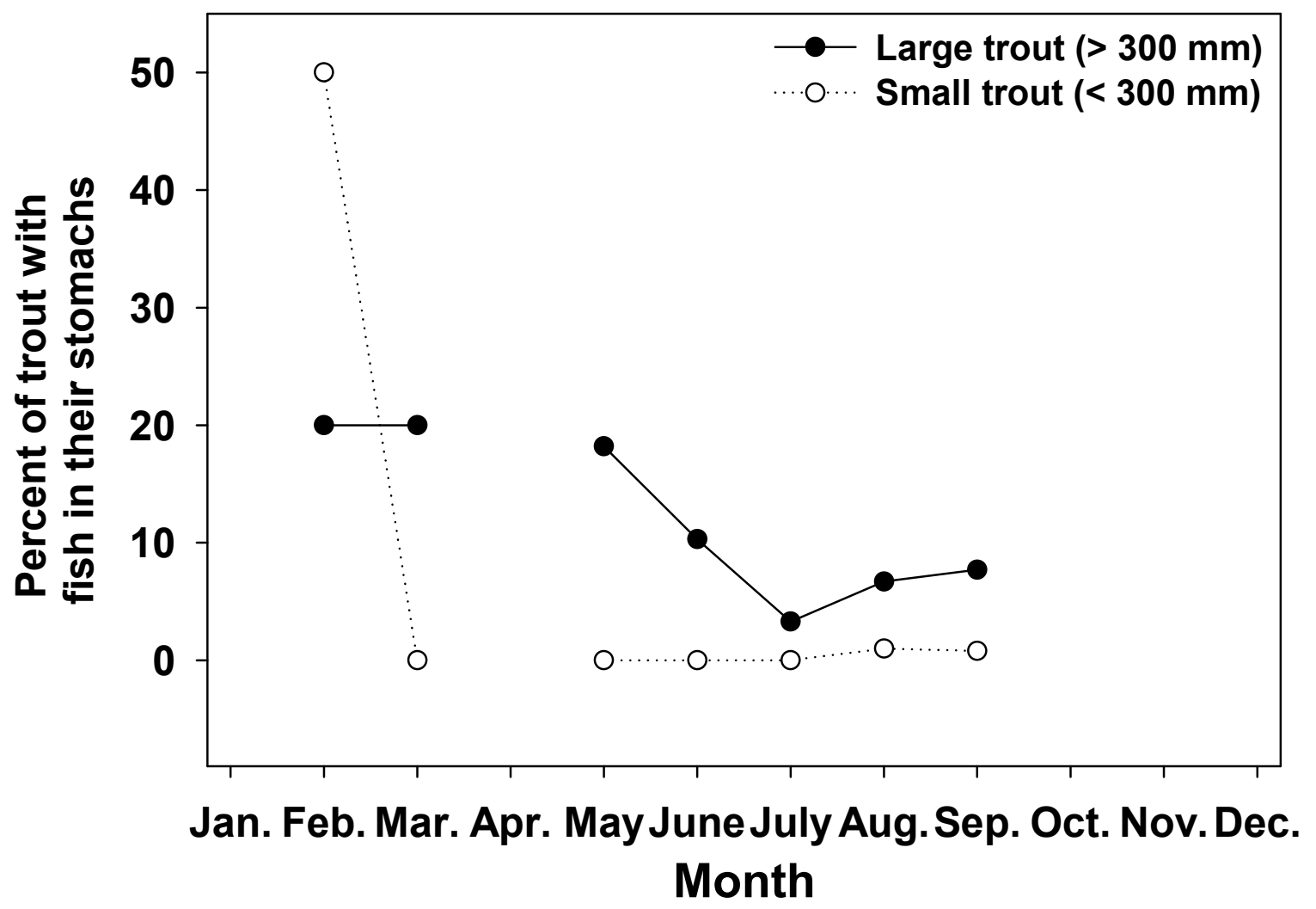

Figure 6. Graph showing percentage of rainbow trout stomachs that contained fish from February 2010 to February 2011. 
Table 1. Numbers of rainbow trout released annually into Lake Scanewa, Washington, 1994- 2010.

[Fish sizes vary substantially for fish released at the Derby Site]

\begin{tabular}{|c|c|c|c|c|c|}
\hline \multirow[b]{2}{*}{ Year } & \multicolumn{3}{|c|}{ Reservoir releases } & \multirow{2}{*}{$\begin{array}{c}\text { Derby Site } \\
\text { Releases }\end{array}$} & \multirow{2}{*}{$\begin{array}{c}\text { Total number o } \\
\text { fish released }\end{array}$} \\
\hline & 1 fish per pound & 2 fish per pound & 3 fish per pound & & \\
\hline 1994 & 12,500 & - & - & - & 12,500 \\
\hline 1995 & 12,500 & - & - & - & 12,500 \\
\hline 1996 & 12,500 & - & 12,500 & - & 25,000 \\
\hline 1997 & 12,500 & - & 12,500 & - & 25,000 \\
\hline 1998 & 12,500 & - & 12,500 & - & 25,000 \\
\hline 1999 & 12,500 & - & 12,500 & - & 25,000 \\
\hline 2000 & 12,500 & - & 12,500 & - & 25,000 \\
\hline 2001 & - & 25,000 & - & - & 25,000 \\
\hline 2002 & - & 25,000 & - & - & 25,000 \\
\hline 2003 & - & 25,000 & - & - & 25,000 \\
\hline 2004 & - & 25,000 & - & - & 25,000 \\
\hline 2005 & - & 20,000 & - & 5,000 & 25,000 \\
\hline 2006 & - & 20,000 & - & 5,000 & 25,000 \\
\hline 2007 & - & 20,000 & - & 5,000 & 25,000 \\
\hline 2008 & - & 20,000 & - & 5,000 & 25,000 \\
\hline 2009 & - & 20,000 & - & 5,000 & 25,000 \\
\hline 2010 & - & 20,000 & - & 5,000 & 25,000 \\
\hline
\end{tabular}

Table 2. Numbers of rainbow trout released at four release sites in Lake Scanewa, Washington, 2010.

[Numbers in parentheses are the number of fish that were PIT tagged from each release group. A total of 20,000 rainbow trout were released during 2010 and 2,082 of these were PIT tagged]

\begin{tabular}{lcrrr}
\hline \multicolumn{1}{c}{ Date } & $\begin{array}{c}\text { Bud Allen } \\
\text { Campground }\end{array}$ & $\begin{array}{c}\text { Cispus Arm of Lake } \\
\text { Scanewa }\end{array}$ & Day Use Area & PUD Boat Launch \\
\hline June 24 & $750(101)$ & $2,000(76)$ & $1,500(75)$ & $750(100)$ \\
July 01 & $1,000(101)$ & $2,000(75)$ & $1,500(77)$ & $500(101)$ \\
July 15 & $450(107)$ & $1,650(100)$ & $900(77)$ & 0 \\
July 29 & $450(102)$ & $1,200(78)$ & $900(79)$ & $450(100)$ \\
August 12 & $300(106)$ & $800(81)$ & $600(82)$ & $300(100)$ \\
August 26 & $300(103)$ & $800(77)$ & $600(79)$ & $300(105)$ \\
$\quad$ Total & $3,250(620)$ & $8,450(487)$ & $6,000(469)$ & $2,300(506)$ \\
\hline
\end{tabular}


Table 3. Numbers of fish that were reported in the catch by boat and shore anglers during a creel survey, Lake Scanewa, Washington, June-November 2010.

\begin{tabular}{lrrr}
\hline Species & Catch by boat anglers & Catch by shore anglers & \multicolumn{1}{c}{ Total catch } \\
\hline Rainbow trout & 1,213 fish $(78 \%)$ & 198 fish $(63 \%)$ & 1,411 fish $(76 \%)$ \\
Coho salmon & 311 fish $(20 \%)$ & 100 fish $(32 \%)$ & 411 fish $(22 \%)$ \\
Chinook salmon & 18 fish $(1 \%)$ & 11 fish $(4 \%)$ & 29 fish $(2 \%)$ \\
Cutthroat trout & 0 fish & 1 fish $(<1 \%)$ & 1 fish $(<1 \%)$ \\
Northern pikeminnow & 5 fish $(<1 \%)$ & 5 fish $(<1 \%)$ & 10 fish $(<1 \%)$ \\
Suckers & 2 fish $(<1 \%)$ & 1 fish $(<1 \%)$ & 3 fish $(<1 \%)$ \\
Mountain whitefish & 1 fish $(<1 \%)$ & 0 fish & 1 fish $(<1 \%)$ \\
Total & 1,550 fish & 316 fish & 1,866 fish \\
\hline
\end{tabular}

Table 4. Catch per hour estimates for rainbow trout anglers in Lake Scanewa, Washington, June-November 2010.

\begin{tabular}{lrr}
\hline Month & $\begin{array}{c}\text { Angler type } \\
\text { (number of anglers) }\end{array}$ & $\begin{array}{c}\text { Catch per hour } \\
\text { (standard deviation) }\end{array}$ \\
\hline \multirow{3}{*}{ June } & Boat (50) & $0.17(0.43)$ \\
& Shore (49) & $0.01(0.07)$ \\
Combined (99) & $0.09(0.32)$ \\
July & Boat (102) & $0.97(0.87)$ \\
& Shore (91) & $0.41(0.83)$ \\
August & Combined (193) & $0.71(0.89)$ \\
& Boat (158) & $2.05(1.79)$ \\
September & Shore (41) & $0.18(0.48)$ \\
& Combined (199) & $1.67(1.78)$ \\
October & Boat (39) & $1.59(1.56)$ \\
& Shore (67) & $0.14(0.43)$ \\
November & Combined (106) & $0.67(1.22)$ \\
& Boat (19) & $0.90(0.80)$ \\
Total & Shore (4) & $0.00(0.00)$ \\
& Combined (23) & $0.75(0.80)$ \\
\hline & Boat (0) & \\
& Shore (9) & $4.09(3.97)$ \\
& Combined (9) & $4.09(3.96)$ \\
\hline
\end{tabular}


Table 5. Summary of the total hours of daylight in each month during June-November 2010, the total number of hours that a creel survey was conducted during this period, and the proportion of daylight hours that were sampled during each month, Lake Scanewa, Washington.

[Hours were rounded to the nearest whole number]

\begin{tabular}{lccc}
\hline Month & $\begin{array}{c}\text { Daylight hours } \\
\text { per month }\end{array}$ & $\begin{array}{c}\text { Creel survey hours } \\
\text { per month }\end{array}$ & $\begin{array}{c}\text { Proportion of daylight } \\
\text { hours sampled }\end{array}$ \\
\hline June & $473 \mathrm{~h}$ & $130 \mathrm{~h}$ & 0.27 \\
July & $477 \mathrm{~h}$ & $130 \mathrm{~h}$ & 0.27 \\
August & $465 \mathrm{~h}$ & $128 \mathrm{~h}$ & 0.27 \\
September & $376 \mathrm{~h}$ & $124 \mathrm{~h}$ & 0.33 \\
October & $337 \mathrm{~h}$ & $130 \mathrm{~h}$ & 0.39 \\
November & $283 \mathrm{~h}$ & $136 \mathrm{~h}$ & 0.48 \\
Total & $2,412 \mathrm{~h}$ & $778 \mathrm{~h}$ & 0.32 \\
\hline
\end{tabular}

Table 6. Summary of the number of anglers that were observed from a boat during a creel survey in Lake Scanewa, Washington, 2010.

[Visible anglers were those that could be seen from the Day Use Area. Non-visible anglers were those that could not be seen from the Day Use Area. The correction factor was calculated by dividing the total number of anglers by the number of visible anglers]

\begin{tabular}{lcccc}
\hline Month & $\begin{array}{c}\text { Number of } \\
\text { visible anglers }\end{array}$ & $\begin{array}{c}\text { Number of non-visible } \\
\text { anglers }\end{array}$ & $\begin{array}{c}\text { Total number } \\
\text { of anglers }\end{array}$ & $\begin{array}{c}\text { Correction } \\
\text { factor }\end{array}$ \\
\hline June & 3 & 0 & 3 & 1.0 \\
July & 3 & 6 & 9 & 3.0 \\
August & 3 & 13 & 16 & 5.3 \\
September & 4 & 2 & 6 & 1.5 \\
October & 1 & 2 & 3 & 3.0 \\
November & 7 & 0 & 7 & 1.0 \\
\hline
\end{tabular}


Table 7. Summary of the estimated number of hours that anglers spent in Lake Scanewa, Washington, 2010.

\begin{tabular}{|c|c|c|c|c|}
\hline Month & Angling group & $\begin{array}{c}\text { Estimated } \\
\text { angling effort }\end{array}$ & $\begin{array}{l}\text { Proportion of anglers } \\
\text { targeting rainbow trout }\end{array}$ & $\begin{array}{c}\text { Estimated rainbow trout } \\
\text { angling effort }\end{array}$ \\
\hline \multirow{3}{*}{ June } & Boat & $837 \mathrm{~h}$ & 0.75 & $624 \mathrm{~h}$ \\
\hline & Shore & $266 \mathrm{~h}$ & \multirow[t]{2}{*}{0.96} & $255 \mathrm{~h}$ \\
\hline & Total & $1,103 \mathrm{~h}$ & & $879 \mathrm{~h}$ \\
\hline \multirow{3}{*}{ July } & Boat & $1,209 \mathrm{~h}$ & \multirow{3}{*}{$\begin{array}{l}1.00 \\
0.99\end{array}$} & $1,209 \mathrm{~h}$ \\
\hline & Shore & $2,185 \mathrm{~h}$ & & $2,161 \mathrm{~h}$ \\
\hline & Total & $3,394 \mathrm{~h}$ & & $3,370 \mathrm{~h}$ \\
\hline \multirow{3}{*}{ August } & Boat & $1,856 \mathrm{~h}$ & \multirow{3}{*}{$\begin{array}{l}0.99 \\
0.98\end{array}$} & $1,845 \mathrm{~h}$ \\
\hline & Shore & $1,876 \mathrm{~h}$ & & $1,831 \mathrm{~h}$ \\
\hline & Total & $3,732 \mathrm{~h}$ & & $3,676 \mathrm{~h}$ \\
\hline \multirow{3}{*}{ September } & Boat & $456 \mathrm{~h}$ & \multirow{3}{*}{$\begin{array}{l}0.95 \\
0.80\end{array}$} & $433 \mathrm{~h}$ \\
\hline & Shore & $1,374 \mathrm{~h}$ & & $1,096 \mathrm{~h}$ \\
\hline & Total & $1,830 \mathrm{~h}$ & & $1,529 \mathrm{~h}$ \\
\hline \multirow{3}{*}{ October } & Boat & $2,690 \mathrm{~h}$ & \multirow{3}{*}{$\begin{array}{l}0.09 \\
0.06\end{array}$} & $249 \mathrm{~h}$ \\
\hline & Shore & $1,563 \mathrm{~h}$ & & $100 \mathrm{~h}$ \\
\hline & Total & $4,253 \mathrm{~h}$ & & $349 \mathrm{~h}$ \\
\hline \multirow{3}{*}{ November } & Boat & $2,627 \mathrm{~h}$ & \multirow{3}{*}{$\begin{array}{l}0.00 \\
0.14\end{array}$} & $0 \mathrm{~h}$ \\
\hline & Shore & $426 \mathrm{~h}$ & & $58 \mathrm{~h}$ \\
\hline & Total & $3,053 \mathrm{~h}$ & & $58 \mathrm{~h}$ \\
\hline \multirow{3}{*}{ Total } & \multirow{3}{*}{$\begin{array}{l}\text { Boat } \\
\text { Shore } \\
\text { Total }\end{array}$} & $9,675 \mathrm{~h}$ & & $4,360 \mathrm{~h}$ \\
\hline & & $7,690 \mathrm{~h}$ & & $5,501 \mathrm{~h}$ \\
\hline & & $17,365 \mathrm{~h}$ & & $9,861 \mathrm{~h}$ \\
\hline
\end{tabular}


Table 8. Summary of observed angler effort, proportion of daylight hours that were surveyed, estimated angler effort, observed catch rates, and estimated catch in Lake Scanewa, Washington, 2010.

\begin{tabular}{|c|c|c|c|c|c|}
\hline Month & $\begin{array}{c}\text { Observed } \\
\text { angling effort }\end{array}$ & $\begin{array}{l}\text { Proportion of daylight } \\
\text { hours surveyed }\end{array}$ & $\begin{array}{c}\text { Estimated angler } \\
\text { effort }\end{array}$ & $\begin{array}{l}\text { Observed catch } \\
\text { rates }\end{array}$ & $\begin{array}{l}\text { Estimated } \\
\text { catch }\end{array}$ \\
\hline \multicolumn{6}{|c|}{ Boat Anglers } \\
\hline June & $171 \mathrm{~h}$ & 0.27 & $624 \mathrm{~h}$ & $0.17 \mathrm{fish} / \mathrm{hr}$ & 106 fish \\
\hline July & $329 \mathrm{~h}$ & 0.27 & $1,209 \mathrm{~h}$ & $0.97 \mathrm{fish} / \mathrm{hr}$ & 1,173 fish \\
\hline August & $505 \mathrm{~h}$ & 0.27 & $1,845 \mathrm{~h}$ & $2.05 \mathrm{fish} / \mathrm{hr}$ & 3,783 fish \\
\hline September & $139 \mathrm{~h}$ & 0.32 & $433 \mathrm{~h}$ & $1.59 \mathrm{fish} / \mathrm{hr}$ & 689 fish \\
\hline October & $96 \mathrm{~h}$ & 0.39 & $249 \mathrm{~h}$ & $0.90 \mathrm{fish} / \mathrm{hr}$ & 224 fish \\
\hline November & $0 \mathrm{~h}$ & 0.48 & $0 \mathrm{~h}$ & $0.00 \mathrm{fish} / \mathrm{hr}$ & 0 fish \\
\hline Total $=$ & $1,243 \mathrm{~h}$ & & $4,361 \mathrm{~h}$ & & 5,975 fish \\
\hline \multicolumn{6}{|c|}{ Shore Anglers } \\
\hline June & $70 \mathrm{~h}$ & 0.27 & $255 \mathrm{~h}$ & $0.01 \mathrm{fish} / \mathrm{hr}$ & 3 fish \\
\hline July & $196 \mathrm{~h}$ & 0.27 & $2,161 \mathrm{~h}$ & $0.41 \mathrm{fish} / \mathrm{hr}$ & 886 fish \\
\hline August & $94 \mathrm{~h}$ & 0.27 & $1,831 \mathrm{~h}$ & $0.18 \mathrm{fish} / \mathrm{hr}$ & 330 fish \\
\hline September & $241 \mathrm{~h}$ & 0.32 & $1,096 \mathrm{~h}$ & $0.14 \mathrm{fish} / \mathrm{hr}$ & 153 fish \\
\hline October & $13 \mathrm{~h}$ & 0.39 & $100 \mathrm{~h}$ & $0.00 \mathrm{fish} / \mathrm{hr}$ & 0 fish \\
\hline November & $28 \mathrm{~h}$ & 0.48 & $58 \mathrm{~h}$ & $4.09 \mathrm{fish} / \mathrm{hr}$ & 237 fish \\
\hline Total $=$ & $642 \mathrm{~h}$ & & $5,501 \mathrm{~h}$ & & 1,609 fish \\
\hline
\end{tabular}


Table 9. Summary of the number of anglers that were interviewed from various counties in the State of Washington, June-November 2010.

\begin{tabular}{lrc}
\hline County of residence & $\begin{array}{c}\text { Number of } \\
\text { anglers }\end{array}$ & $\begin{array}{c}\text { Percentage of } \\
\text { anglers }\end{array}$ \\
\hline Benton & 1 & 0.08 \\
Chelan & 9 & 0.74 \\
Clark & 10 & 0.82 \\
Cowlitz & 16 & 1.32 \\
Grant & 3 & 0.25 \\
Grays Harbor & 4 & 0.33 \\
King & 40 & 3.29 \\
Kitsap & 2 & 0.16 \\
Lewis & 513 & 42.26 \\
Mason & 1 & 0.08 \\
Pacific & 10 & 0.82 \\
Pierce & 330 & 27.18 \\
Skamania & 2 & 0.16 \\
Snohomish & 15 & 1.24 \\
Stevens & 1 & 0.08 \\
Thurston & 69 & 5.68 \\
Yakima & 163 & 13.43 \\
Out of State & 25 & 2.06 \\
Total & 1,214 & 100.00 \\
\hline
\end{tabular}


Publishing support provided by the U.S. Geological Survey

Publishing Network, Tacoma Publishing Service Center

For more information concerning the research in this report, contact the Director, Western Fisheries Research Center

U.S. Geological Survey, 6505 NE 65th Street

Seattle, Washington 98115

http://wfrc.usgs.gov/ 


\section{奇}

